\title{
„AZ OLTALMAT ADÓ ÜVEGHÁZ”
}

\author{
SZEKEREs ÁGota \\ az Eötvös Loránd Tudományegyetem Bárczi Gusztáv Gyógypedagógiai Kar \\ egyetemi adjunktusa \\ agota.szekeres@barczi.elte.hu
}

Ez a könyvismertetés egy 2011-ben megjelent tanulmánykötetet mutat be. A címben olvasható hasonlatot az egyik tanulmányból vettem, amelyben az integráló intézményre keresett metaforát egy kolléga. Remélhetőleg az írások segítenek abban, hogy az intézmények meg tudjanak felelni ennek a metaforának és tényleges, hatékony segítséget tudjanak nyújtani a sajátos nevelési igényü gyermekeknek az integráló környezetben. A tanulmányok ismertetésénél három lényeges szempontot emelnék ki: elsősorban leíró jellegü bemutatásra törekszem, az integrált nevelés-oktatás szempontjából releváns elemeket emelem ki, valamint olyan kutatásokra koncentrálok, amelyek hatással lehetnek az együttnevelés gyakorlatára.

Mészáros Andrea tanulmányában az enyhe értelmi fogyatékosság diagnosztizálásakor alkalmazott WICS-IV gyermek-intelligenciateszt szerepéről olvashatunk. A bemutatott esettanulmány segíthet megérteni azt, hogy a diagnózis során kapott eredmények hogyan támogathatják az intervenciós stratégiák kialakítását. A gyógypedagógusoknak - amikor szembesülnek egy szakértői véleménnyel - tisztában kell lenniük azzal, hogy a tesztben megjelenő indexek és szubtesztek mit és miért mérnek, hogy ennek mentén tudják megtervezni a gyermek pedagógiai célú (re)habilitációs fejlesztő foglalkozását.

Józsa Krisztián írásából a DIFER (Diagnosztikus fejlődésvizsgáló és kritériumorientált fejlesztő rendszer 4-8 évesek számára) programcsomaggal végzett vizsgálatokat ismerhetjük meg. A DIFER program alkalmazása - a diagnosztizáláson túl - segítséget jelenthet az óvodapedagógusoknak a kiscsoportos fejlesztés megvalósításához is. A programcsomagot tanulásban akadályozott gyermekek körében is kipróbálták, első körben gyógypedagógiai intézménybe járók között, de már vannak adatok az integráltan tanuló gyermekek fejlettségére vonatkozóan is. A vizsgálatok alapján megállapítható, hogy a tanulásban akadályozott gyermekek elemi alapkészségeinek fejlettsége jelentősen elmarad a hasonló életkorú társaikétól, és náluk a készségfejlődés is lassúbb, időben elhúzódóbb folyamat. A többségi pedagógusoknak akár az óvodai, akár az iskolai együttnevelés során nem szabad erről megfeledkezniük, hiszen az eltérő követelmények, az eltérő tanulási utak tervezése során is hasznos mindezt figyelembe venni. A DIFER jó eszköz lehet mind a peda- 
gógusok, mind pedig a gyógypedagógusok kezében a gyermekek korai szürésére, valamint a megfelelő (gyógy)pedagógiai támogatás megtervezésére.

Meilinger Anita tanulmányában a szülőszerep kérdéseit boncolgatja. Teszi ezt szülőként és gyógypedagógusként egyaránt. A szerző hangsúlyozza az ún. összetett krízis időszakának fontosságát, amelyet csak a tanulásban akadályozott gyermeket nevelő szülők élnek át. Ez azt jelenti, hogy a fogyatékosság tényével való szembesülés és a beiskolázást érintő krízis egybeesik, így felerősítik egymást, amely nem könnyíti meg az iskolaválasztással kapcsolatos döntést. A szerző kis elemszámú mintán mutatja be, hogy az együttnevelés választása sokszor nem tudatos, autonóm döntés, így az elfojtott érzelmi motívumok túlzott szerepet kaphatnak a döntés folyamatában (például csodavárás). Magyarul még kevés olyan tanulmány olvasható, amely integráltan tanuló enyhén értelmi fogyatékos gyermekek szüleinek iskolaválasztási motivációját ismerteti, illetve amely részletesen tárgyalná a szülök elfogadási mechanizmusait. Más fogyatékosságok esetén már vannak mindezzel kapcsolatos publikációk (Kálmán, 2004; Radványi, 2006).

Szekeres Ágota első tanulmányában enyhén értelmi fogyatékos gyermekek beilleszkedéséről, szociális és emocionális integrációjának sikerességéről olvashatunk. Az elmúlt évek során egyre több gyermek tanult integrált körülmények között, így fontos tudnunk, hogyan érzik magukat, mennyire lett, lehet sikeres a beilleszkedésük. A hazai nagymintás kutatás (200 integráltan tanuló, enyhén értelmi fogyatékos gyermek) eredményeiből kiemelendö, hogy az enyhén értelmi fogyatékos fiúk és lányok beilleszkedése eltérö. A fiúk szociális integrációja gyakorlatilag megvalósul, míg a lányok esetében ez nem mondható el. Itthon ehhez hasonló kutatás történt hallássérült tanulók esetében (Perlusz, 2000), míg nemzetközi szinten már az országok helyzetét hasonlítják össze a szociális beilleszkedés szempontjából (Frostad és Pijl, 2007; Koster és mtsai, 2007; Mand, 2007).

Szekeres Ágota másik tanulmánya összefoglalja az integrációban résztvevők (pedagógusok, gyógypedagógusok, szülők, gyermekek) szemszögéből az együttnevelés megítélését. A participáció - a fogyatékos személyek egyre nagyobb mértékben megvalósuló társadalmi részvétele - érdekében felveti az önattitüd vizsgálatának a lehetőségét is. A tanulmány elsősorban olyan kutatások összefoglalását adja, amelyek fontos adalékul szolgálhatnak a szülökkel való együttmüködéshez.

Fazekasné Fenyvesi Margit a tanulásban akadályozott gyermekek megsegítésének egy másik aspektusát mutatja be, mégpedig a metakogníció fejlesztésének lehetőségeit (személy szerinti tervezés, feladatra vonatkozó tervezés, stratégiára vonatkozó tervezés). A szerző a matematika és az olvasás terén ír le olyan metakogníciót segítő eljárásokat, amelyeket integrációban akár a többségi pedagógus is hatékonyan alkalmazhat.

Miksztai-Réthey Brigitta tanulmányában fejlesztö- és oktatóprogramokat ismertet és elemez abból a szempontból, hogy tanulásban akadályozott tanulók esetében melyik hogyan használható. Jelentős részüket sikeresen alkalmazzák a gyógypedagógiai 
intézményekben, így az integráció során is érdemes kipróbálni ezeket. A szerző foglalkozik azokkal a módszertani szempontokkal, amelyek segítik a pedagógusokat abban, hogy eldöntsék, melyik szoftver támogatja legjobban az adott gyermek tanulását. A fejezet végén egy linkgyüjtemény található azokból az online anyagokból és ingyenesen letölthető szoftverekböl, amelyek hasznosak lehetnek akár a tanórai munkában, akár a fejlesztő foglalkozásokon.

Virányi Anita azt a kérdést boncolgatja, hogy az enyhén értelmi fogyatékos gyermekek a digitális bevándorlók vagy a digitális bennszülöttek csoportjába tartoznak-e. Egy gyógypedagógusnak - aki akár integrált közegben segíti a tanulásban akadályozott gyermekeket - ismernie kell az infokommunikációs eszközök széles körét, beleértve az elektronikus, a digitális fejlesztő programokat vagy akár a web 2.0 technológia eszközeit is. Mindezek ismerete egy sérült/fogyatékos/akadályozott fiatal számára, akár a munkakeresés, -vállalás folyamatában is hasznos lehet.

Szauer Csilla és munkatársainak tanulmánya az együttnevelés hosszú távú következményeivel foglalkozik, elsősorban a társadalmi beilleszkedéssel, beleértve a munkaerö-piaci integrációt is. A bemutatott ígéretes gyakorlat, a Munkahelyi Gyakorlat program egyik fö jellemzője az, hogy nyílt munkaerö-piaci munkahelyen valósul meg. A program eddigi hatásai közül kiemelendő, hogy visszacsatolást nyújt az intézmények számára arról, hogy munkájuk hosszútávon is sikeres, hiszen tanulóik egy részének lehetséges az integrált munkavállalás. Egy másik fontos szempontként merült fel a településeken élő lakosság toleranciájának növekedése az értelmi fogyatékos fiatalok mindennapi életébe való betekintéssel.

Stefanik Krisztina írásában konkrét tanácsokat fogalmaz meg a gyógypedagógia számára az autizmus spektrumzavar kapcsán. Az üzenetek fontosak a többségi pedagógia számára is, hiszen az integráció során egyre több autizmussal élő vagy autisztikus tüneteket mutató gyermekkel találkozhatunk. A szerző felhívja a figyelmet a tüneti kép heterogenitására, amelyet nem szabad figyelmen kívül hagyni a megsegítés tervezése során. Az oki háttér kapcsán pedig kizárja a pszichogén okok szerepét, így lebontva azt a téves nézetet, hogy a rossz szülői bánásmód okozhatja az autizmust. Hangsúlyozza azt a tényt, hogy az autizmussal élő gyermekek megsegítése kreatív pedagógiai munkát igényel.

A kötet utolsó tanulmányát Pénzes Éva írta, aki gyógypedagógusok és pedagógusok rejtett érzelmi megnyilvánulásait vizsgálja az integrációval és a fogyatékos gyermekekkel kapcsolatosan metaforakutatás segítségével. A kutatás összegzéseként azt a veszélyt tudta beazonosítani, amely szerint az integrációban dolgozó kollégák hol védeni szeretnék a fogyatékos gyermekeket a veszélyektől, hol pedig magukat szeretnék eltávolítani a veszélytől (aki maga a gyermek). Mégis olvashatunk olyan metaforákat, amelyek arról biztosítanak bennünket, hogy jó úton haladunk, amikor az integráció ösvényén járunk: „Az integráló intézmény olyan, mint egy befogadó, meleg fészek, amely minden fiókának egyforma ellátást nyújt és meleget ad." (Pénzes, 2011, 242. o.). 
Az integráló intézmények feladata többek között az, hogy olyan biztonságos légkört teremtsenek, amelyben minden gyermek - legyen az akár sajátos nevelési igényü, akár tehetséges, akár hátrányos helyzetü - jól érzi magát, megtalálja a számára megfelelő, kihívást jelentő feladatokat és sikeresen készül fel a későbbi társadalmi beilleszkedésre. A kötetben olvasható tanulmányok ehhez nyújtanak segítséget korszerủ szakirodalmak felhasználásával, valamint a gyakorlatból vett példák széles körü bemutatásával.

\section{Irodalom}

Frostad, P., Pijl, S. J. (2007): Does being friendly help in making friends? The relation between the social position and social skills of pupils with special needs in mainstream education. European Journal of Special Needs Education, Vol. 22, No. 1, 15-30.

Kálmán Zsófia (2004): Bánatkö. Sérült gyermek a családban. Bliss Alapítvány, Budapest

Koster, M., Pijl, S. J., van Houten, E., Nakken, H. (2007): The social position and development of pupils with SEN in mainstream Dutch primary schools. European Journal of Special Needs Education, Vol. 22, No. 1, 31-46.

Mand, J. (2007): Social position of special needs pupils in the classroom: a comparison between German special schools for pupils with learning difficulties and integrated primary classes. European Journal of Special Needs Education, Vol. 22, No. 1, 7-14.

Pénzes Éva (2011): A metaforakutatás lehetőségei a (gyógy)pedagógiában. In: Papp Gabriella (szerk.): A diagnózistól a foglalkozási rehabilitációig. ELTE Eötvös Kiadó, ELTEBGGYK, Budapest, 235-247.

Perlusz Andrea (2000): A hallássérült gyermekek integrációja. Fogyatékosok Esélye Közalapítvány, Budapest

Radványi Katalin (2006): Sérült gyermek a családban. In: Várkonyi Ágnes (szerk.): Ismerj meg,... Hogy megérts! Ismeretek a sajátos nevelési igényü gyermekeket gondozó és nevelö szakemberek és családok részére. Semmelweis Egyetem Hajnal Imre Egészségügyi Föiskolai Kar, Budapest, 15-25.

Papp Gabriella (szerk., 2011): A diagnózistól a foglalkozási rehabilitációig. ELTE Eötvös Kiadó, ELTE-BGGYK, Budapest, 248 oldal 